\title{
Wild Pacific oyster Magallana gigas (Thunberg, 1793) populations in Romanian Black Sea waters - friend or foe?
}

\author{
Ana-Maria Krapal11, Marin Ioniță², Mihaela Caplan², Elena Buhaciuc-Ionițăa \\ 1 “Grigore Antipa" National Museum of Natural History, 1 Kiseleff, 011341 Bucharest, Romania \\ 2 "Natura-Z" Research and Education Society for Biodiversity Conservation, 123 Dorului Str., 900374 \\ Constanţa, Romania \\ Corresponding author: Ana-Maria Krapal (ana.krapal@antipa.ro)
}

Received 4 December 2019 | Accepted 19 December 2019 | Published 31 December 2019

Citation: Krapal A-M, Ioniță M, Caplan M, Buhaciuc-Ioniță E (2019) Wild Pacific oyster Magallana gigas (Thunberg, 1793) populations in Romanian Black Sea waters - friend or foe? Travaux du Muséum National d'Histoire Naturelle "Grigore Antipa" 62(2): 175-183. https://doi.org/10.3897/travaux.62.e49074

\begin{abstract}
A relatively small population of Magallana gigas was discovered near the Agigea harbor (Constanța, Romania) in 2017. The DNA barcoding method was used to confirm the morphological identification of the species. We consider this colony to be the first instance of a possibly stable Pacific oyster population in the Black Sea, outside of farming activities. The possible impact on native ecosystems is briefly discussed.
\end{abstract}

\section{Keywords}

benthic ecosystems, climate change, Crassostrea gigas, DNA barcoding, ecological niche, feral populations, invasive species.

\section{Introduction}

The Pacific oyster, Magallana (Crassostrea) gigas (Thunberg, 1793), is a highly appreciated shellfish species. Native to the Far East Pacific, it is being used worldwide in aquaculture and has been extensively and successfully introduced in temperate and tropical areas (Ruesink et al. 2005). The first introduction in Europe took place in France in 1966, followed by a series of similar events along the northern European 
Atlantic coasts where it established stable and even flourishing wild populations (Shatkin et al. 1997, Lallias et al. 2015). In Romania, M. gigas was first recorded in 1995 (Micu 2004). Between 2001 and 2003, intensive off-shore procedures were carried out for the introduction and establishment of the species in the Black Sea for farming purposes (Zaharia and Crivăț 2017). Live isolated specimens have been found in the Romanian Black Sea waters since 2003 (Micu 2004), some of them fixed on the rocky substrate near Constanța (Skolka and Gomoiu 2004). Also, after winter storms, fresh shells of Pacific oyster can frequently be seen on the beaches near Constanța, as was the case in the 2003-2004 winter when valves of 1-8 cm in length were found (Skolka and Gomoiu 2004).

Ostreid species have widely variable shells depending on the substrate where the spat settles (Poppe and Goto 2000). These highly variable morphological characters make it quite difficult to differentiate between ostreid species (Dridi et al. 2008). This is where molecular methods, such as DNA barcoding, are implemented in order to help identify such difficult species. The ostreid specimens discovered in the Romanian Black Sea were identified based on morphological characters and the DNA barcoding method was used to confirm the morphological identification.

This paper presents the first record of a wild colony of $M$. gigas discovered during diving sessions carried out in the Agigea harbor (south of Constanța) for quantitative and qualitative studies of the zoobenthos, in 2017-2018. Possible interactions with native fauna are also discussed.

\section{Materials and methods}

Diving sessions were carried out in August and October 2017 in Agigea harbor (south of Constanța, Romania), for a quantitative and qualitative study of the zoobenthos. The oyster colony was discovered in a rocky bottom area in the Agigea harbor $\left(44.098204^{\circ} \mathrm{N}, 28.695071^{\circ} \mathrm{E}\right.$ ) (Figs 1, 2). All oyster individuals were counted and measured in length using an underwater measuring tape in order to estimate the age related to the growth rate. The entire surface occupied by the oyster colony and the depth range were measured using a graded rope with lead weights. The oyster density was assessed by applying the relevé method using a $1 \mathrm{~m}$ side metallic quadrate. Two individuals were collected and preserved at $-20^{\circ} \mathrm{C}$ for further DNA analyses.

Morphological identification. Characters such as shell color, shape and length, aspect and color of the adductor muscle scar were assessed and compared to oyster descriptions published in literature (Lucas 1982, Poppe and Goto 2000, Zenethos et al. 2003).

DNA barcoding. Genomic DNA was extracted from foot muscle tissue of two oyster individuals using the commercial ISOLATE II Genomic DNA Kit (Bioline meridian BIOSCIENCE, London, UK), following the producer's instructions. A partial COI (Cytochrome C oxidase subunit I) fragment was selected as barcode 
and amplified using the HCO2198/LCO1490 primer pair (Folmer et al. 1994). The PCR reaction was carried out in $50 \mu \mathrm{l}$ final reaction volume containing about 100 ng DNA template, $1 \mathrm{U}$ of GoTaq ${ }^{\oplus} 2$ Flexi DNA Polymerase (Promega Corporation, Madison, WI, USA), 1 X Green GoTaq ${ }^{\oplus}$ Flexi Buffer ( $\mathrm{pH}$ 8.5), $2 \mathrm{mM} \mathrm{MgCl}, 0.1 \mathrm{mM}$ of each dNTP, $0.1 \mu \mathrm{M}$ of each primer and water up to final volume. The PCR conditions were comprised of an initial denaturation at $95^{\circ} \mathrm{C}$ for $2 \mathrm{~min}, 5$ cycles of $94^{\circ} \mathrm{C}$ for $30 \mathrm{~s}, 45^{\circ} \mathrm{C}$ for $1 \mathrm{~min} 30 \mathrm{~s}, 72^{\circ} \mathrm{C}$ for $1 \mathrm{~min}$, followed by 35 cycles of $94^{\circ} \mathrm{C}$ for $30 \mathrm{~s}$, $52^{\circ} \mathrm{C}$ for $1 \mathrm{~min} 30 \mathrm{~s}, 72^{\circ} \mathrm{C}$ for $1 \mathrm{~min}$, and a final elongation step of $5 \mathrm{~min}$ at $72^{\circ} \mathrm{C}$. The amplified fragments were visualized on a $1.5 \%$ agarose gel stained with ethidium bromide and purified using the FavorPrep ${ }^{\text {tw }}$ Gel/PCR Purification Kit (FAVORGEN ${ }^{\circ}$ Biotech Corp., Changzhi, Taiwan). The amplicons were sequenced using the commercial services of Macrogen Europe (Amsterdam, Netherlands). The sequences were manually checked for potential sequencing errors in CodonCode Aligner v3.7.1 (CodonCode Corporation, Dedham, MA, USA), then used to query the GenBank online database Nucleotide collection (nr/nt) using the Megablast algorithm (optimized for highly similar sequences) (Zhang et al. 2000, Morgulis et al. 2008) in the BLAST online application (https://blast.ncbi.nlm.nih.gov/Blast.cgi).

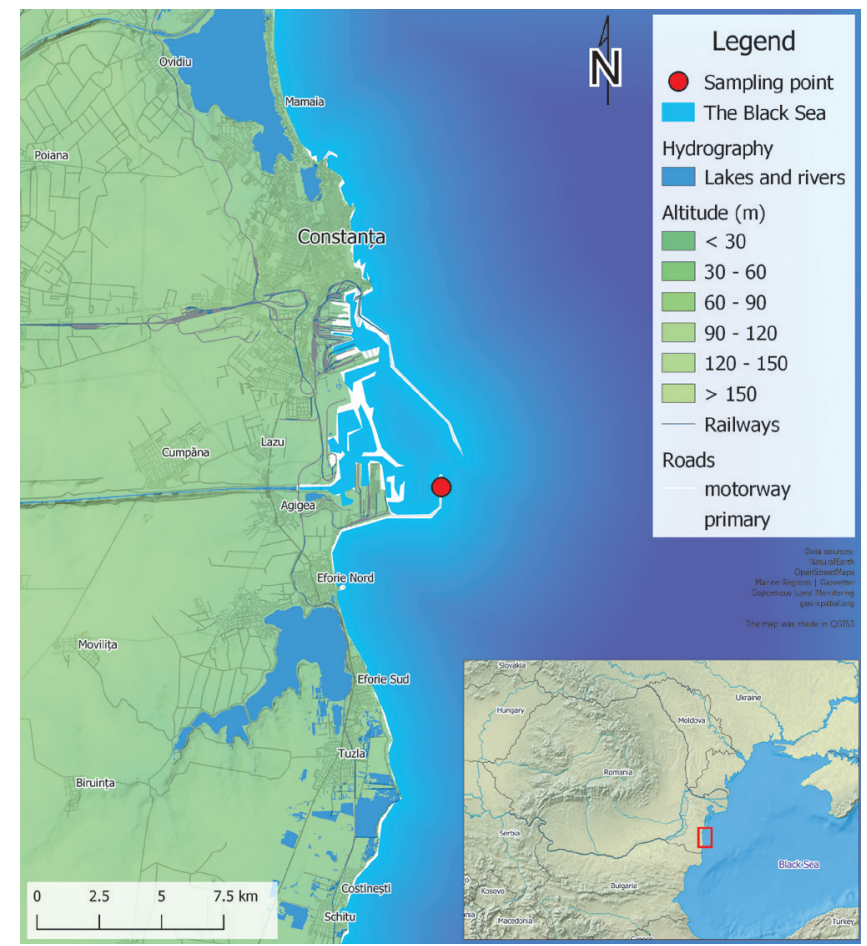

Figure 1. The location of the new Magallana gigas population at the Romanian Black Sea coast is indicated by the red dot. 


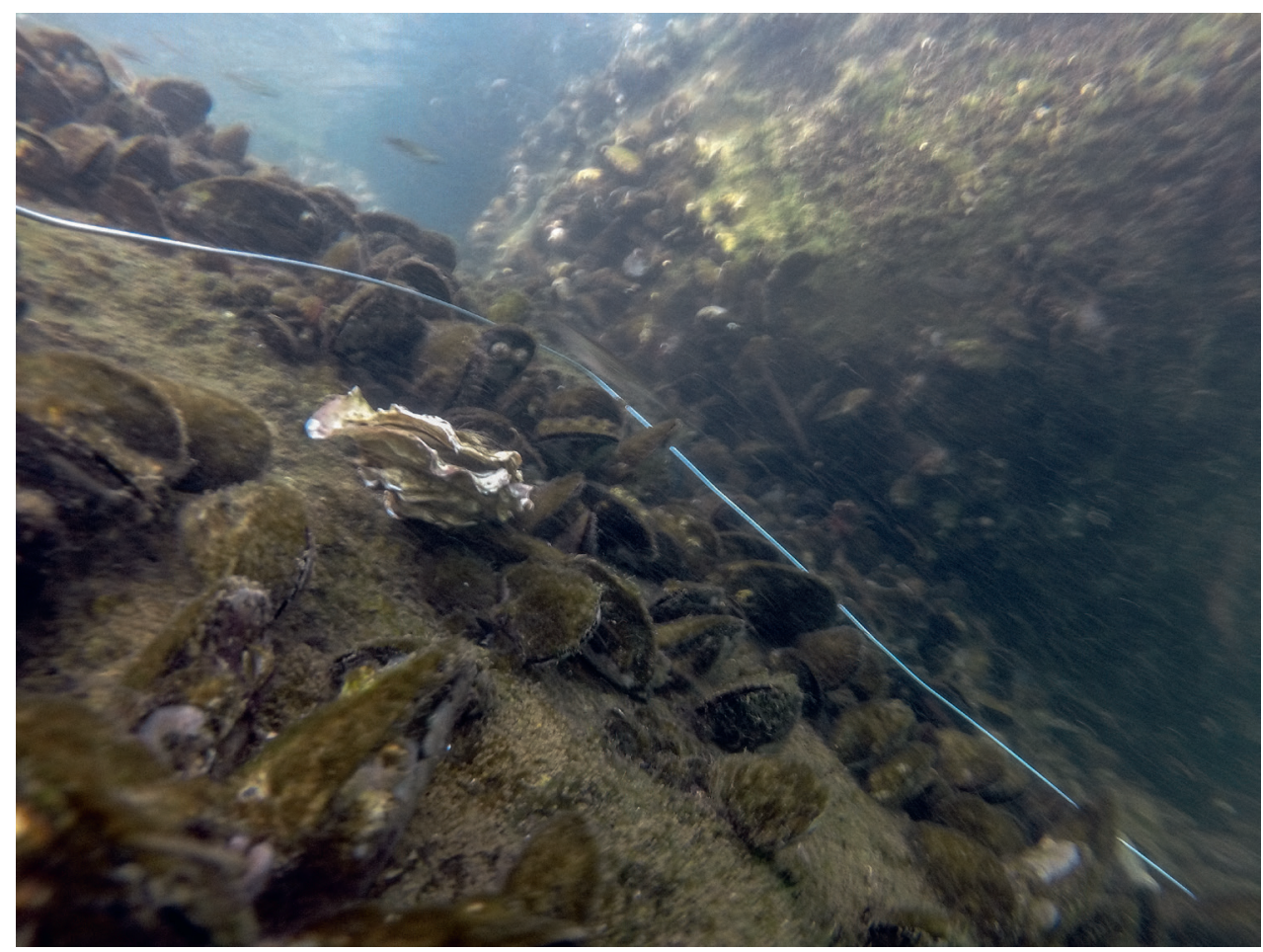

Figure 2. Magallana gigas habitat from the Romanian Black Sea littoral

\section{Results}

The depth range where the oyster colony was located varied between 4 and $10 \mathrm{~m}$, with a total covered surface of $\sim 350 \mathrm{~m}^{2}$. The density was relatively low, with an average of 1.16 oysters $/ \mathrm{m}^{2}$.

Diagnosis. Most of the analyzed oysters presented a roundish shell with extensive fluting, similar to M. gigas individuals described from hard substrata (Lucas 1982, Zenethos et al. 2003), and only a few young individuals presented an elongated shell. Shell inequivalve with the right valve flattened and the left valve larger and convex, white with purple patches, similar to the description of Zenethos et al. (2003). The adductor muscle scar heavily colored (Poppe and Goto 2000). Shell length varied between 5.2 and $18.6 \mathrm{~cm}$, with an average size of $10.35 \mathrm{~cm}$ (Fig. 3).

DNA barcoding. Two 638bp COI sequences were obtained and used to query the GenBank online nucleotide database. 25 matches to sequences of Crassostreal Magallana gigas specimens from the native area of the species (Pacific Ocean, China and Japan) were obtained, with similarity levels between $99.4 \%$ and $100 \%$. These results confirmed the species identification based on morphological criteria. 

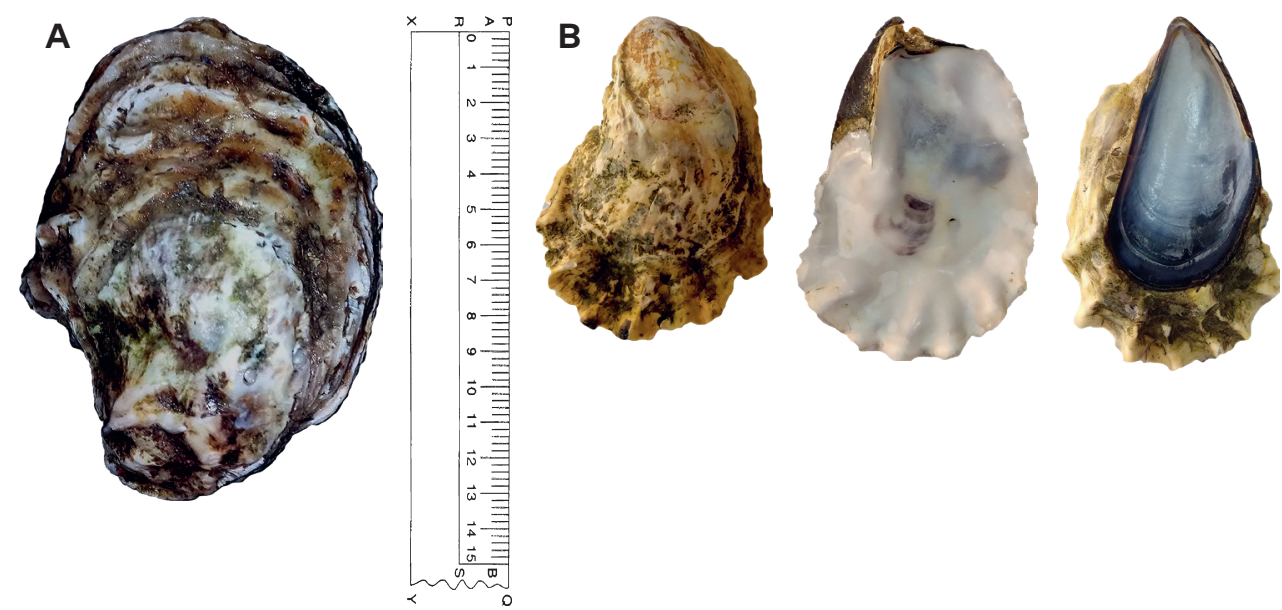

Figure 3. Magallana gigas specimens from the Romanian Black Sea waters (scale in cm). (A) The largest collected specimen; (B) Medium sized specimens.

\section{Discussion}

M. gigas was first introduced in the northern Black Sea coastal waters from the Sea of Japan to replace the native Ostrea edulis that was steadily harvested until the arrival of Rapana venosa in the '30s-'40s, the voracious gastropod that decimated the native oyster populations (Grossu 1986). A sole individual (only the shell) of M. gigas was previously discovered in the Black Sea outside of mariculture facilities, in the Odessa Bay in 2007. The shell was assessed as being over 12 years old and most likely the result of mariculture attempts in the coastal waters of the Caucasus since the 1980s (Kovtun and Zolotarev 2008). Despite being listed as one of the worst 100 invaders due to its high reproductive potential and plasticity (DAISIE 2009), it was generally considered that the Pacific oyster was unable to survive in the Black Sea without artificial hydrobiological conditions. This is why, despite intensive farming activities on the northern shores, it could not survive outside farming facilities, due to the special conditions of the Black Sea, mainly the salinity, the rhopic factor and the average water temperatures, which have a strong effect on the spawning, growth, and survival of this species (Fabioux et al. 2005, Anglès d'Auriac et al. 2017, Ibarra et al. 2017). Also, the Romanian Black Sea conditions are far from optimal for the Pacific oyster in regards to exposure, waves, depth, average minimum temperature, and salinity (Zaharia and Crivăț 2017). Therefore, the discovery of the wild population near the Agigea harbor was unexpected. Several acclimating attempts of the Pacific oyster to farming in the Romanian Black Sea coastal waters were carried out by the National Institute for Marine Research and Development "Grigore Antipa" in collaboration with a private mariculture farm. These experiments were conducted between 2001-2003, in laboratory and off-shore conditions 
in the Agigea area (Zaharia and Crivăt 2017). Thus, the most likely source of the M. gigas colony near Agigea is the stock used by the mariculture farm established here, but in order to confirm or infirm the origins of the colony, further molecular studies will be needed.

The relatively small number of Pacific oyster individuals found in the Agigea population and their small average size, correlated with the average growth rate of $4-5 \mathrm{~cm}$ in the first year and up to approximately $7.5 \mathrm{~cm}$ in the second year (Diederich 2006), suggest that this population is young, around 5 years old. Only larger oysters were attached to the rocky substrate, while most of the small and medium sized individuals were attached to Mediterranean mussels (Mytilus galloprovincialis). This might suggest that either the oyster and mussel colonies developed roughly at the same time, or the mussels settled at a later time and developed at a faster rate, covering a wider rocky area than the oysters. Both situations can be explained by the fact that the conditions in the Romanian Black Sea waters are not optimal for the settlement and development of M. gigas (Zaharia and Crivăț 2017), while M. galloprovincialis is a native species that thrives in these conditions, even forming a specific littoral biocenosis associated with several benthic communities characteristic to the Romanian Black Sea coast, habitats such as infralittoral rock with M. galloprovincialis and biogenic reefs (Băcescu et al. 1971, Teacă et al. 2010, Galatchi et al. 2014).

M. gigas is considered, along with all ostreid species, a successful ecosystem engineer. These species can modify ecosystems by changing or providing new substrates, creating new habitats, altering local hydrodynamics or dynamics of nutrients and sediments (Ruesink et al. 2005, Padilla 2010). The interaction of the Pacific oyster with native species in local ecosystems was assessed so far in several studies with quite opposite results, depending on the habitat, species assemblages, and climate conditions (Ruesink et al. 2005, Padilla 2010, Troost 2010). There is evidence of negative impact of rapidly developing Pacific oyster colonies on blue mussel populations Mytilus edulis in the Wadden Sea, Denmark (Reise 1998, Diederich 2006, Reise et al. 2017). However, there are signs of increased biodiversity associated with non-native Pacific oyster reefs in the Oosterchelde estuary, Netherlands (van Broekhoven 2005). Also, relatively short-term studies have shown no discrepancy between associated communities of native O. edulis and non-native $M$. gigas populations in different locations (Zwerschke et al. 2016), while studies on sympatric populations of $O$. edulis and $M$. gigas over a longer period of time revealed significant differences between associated epibiota (Guy et al. 2018). In the case of M. gigas populations established in the Strait of Georgia, Canada, though, the Pacific oyster has occupied an ecosystem niche that was available at the time of introduction, and offered a very good substrate for native barnacle species (Ruesink et al. 2005). There are also some cases that lead to our tentative hypothesis of $M$. gigas filling the empty niche of $O$. edulis where the habitat requirements of the two species overlap (e.g. Troost 2010). 
As was expected, no Black Sea native oysters were found during the zoobenthos survey. This encourages us to believe that the nonindigenous $M$. gigas might occupy the empty spot left in rocky benthic ecosystems at the Romanian Black Sea littoral by the disappearance of native $O$. edulis. Thus, the newly established population of M. gigas in the Black Sea could fill a vacant ecosystem niche and act as a positive ecological development, as the Black Sea native oyster banks have disappeared from the Romanian coast due to the invasive veined rapa whelk Rapana venosa (Gomoiu 1972).

\section{Conclusions}

The presence of the wild M. gigas colony in the Romanian Black Sea waters confirms the high adaptability to salinity variations and rhopic factor differences of the species and suggests that it is already acclimated to the special conditions of these waters. The relatively small number of individuals and their small average size suggest that this colony is young, about 5 years old. The source of this colony is most likely the mariculture farm located not very far, thus this population could be considered feral. The young individuals that were found ( $\sim 5 \mathrm{~cm}$ in length) and the long period of time time between acclimating attempts of the Pacific oyster for farming in the Romanian Black Sea coastal waters ( 15 years) suggest that the reproduction of M. gigas in natural conditions is quite possible, but further studies and monitoring are needed to determine whether M. gigas managed to successfully reproduce and form stable colonies in the Black Sea conditions, without human intervention. A genetic approach may indicate the origin of the settled $M$. gigas and ecological studies will assess the future development of this young population in the Romanian Black Sea waters in the context of climate change and ocean acidification.

\section{Aknowledgements}

We thank our colleague, Andrei Ștefan, for the help provided in creating the map presented in this paper.

\section{References}

Anglès d'Auriac MB, Rinde E, Norling P, Lapègue S, Staalstrøm A, Hjermann DØ, Thaulow J (2017) Rapid expansion of the invasive oyster Crassostrea gigas at its northern distribution limit in Europe: Naturally dispersed or introduced? PLoS ONE 12(5): e0177481.

Băcescu MC, Müller GI, Gomoiu MT (1971) Ecologie Marină. Vol. IV. Cercetări de ecologie bentală în Marea Neagră - Analiza cantitativă, calitativă și comparată a faunei pontice [Marine Ecology. Vol. IV. Benthic ecology research in the Black Sea - Quantitative, 
qualitative, and comparative analysis of Pontic fauna]. Editura Academiei Republicii Socialiste România, Bucharest, 357 pp. [in Romanian]

DAISIE (2009) Handbook of alien species in Europe. Springer Netherlands, 399 pp.

Diederich S (2006) High survival and growth rates of introduced Pacific oysters may cause restrictions on habitat use by native mussels in the Wadden Sea. Journal of Experimental Marine Biology and Ecology 328: 211-227.

Fabioux C, Huvet A, le Souchou P, le Pennec M, Pouvreau S (2005) Temperature and photoperiod drive Crassostrea gigas reproductive internal clock. Aquaculture 250(1-2): 458-470.

Folmer O, Black M, Hoeh W, Lutz R, Vrijenhoek R (1994) DNA primers for amplification of mitochondrial cytochrome c oxidase subunit I from diverse metazoan invertebrates. Molecular Marine Biology and Biotechnology 3: 294-299.

Galatchi M, Nenciu MI, Niţă VN, Marin O, Tiganov G (2014) Life in the Black Sea - Sites of Community Importance along the Romanian Black Sea Coast. Editura Aureo, Oradea, $48 \mathrm{pp}$.

Gomoiu MT (1972) Some ecological data on the gastropod Rapana thomasiana Crosse along the Romanian Black Sea shore. Cercetări marine - Recherches Marines, IRCM, Constanța 4: 169-180.

Grossu AV (1986) Gastropoda Romaniae 1. Prosobranchia, Opistobranchia. Editura Litera, Bucharest, 523 pp. [in Romanian]

Guy C, Blight A, Smyth D, Roberts D (2018) The world is their oyster: Differences in epibiota on sympatric populations of native Ostrea edulis and non-native Crassostrea gigas (Magallana gigas) oysters. Journal of Sea Research 140: 52-58.

Ibarra AM, Ascencio-Michel R, Ramírez JL, Manzano-Sarabia M, Rodríguez-Jaramillo C (2017) Performance of diploid and triploid Crassostrea gigas (Thunberg, 1793) grown in tropical versus temperate natural environmental conditions. Journal of Shellfish Research 36(1): 119-139.

Kovtun OA, Zolotarev VN (2008) The first find of the oyster Crassostrea gigas (Bivalvia, Ostreidae) in Odessa Bay (the Black Sea). Vestnik Zoologii 42: 262. [in Ukrainian]

Lallias D, Boudry P, Batista FM, Beaumont A, King JW, Turner JR, Lapègue S (2015) Invasion genetics of the Pacific oyster Crassostrea gigas in the British Isles inferred from microsatellite and mitochondrial markers. Biological Invasions 17: 2581-2595.

Lucas M (1982) The genus Crassostrea in Europe. La Conchiglia 14: 18-19.

Micu D (2004) Annotated checklist of the marine Mollusca from the Romanian Black Sea. In: Ozturk B, Mokievsky VO, Topaloglu B (Eds) International Workshop on Black Sea Benthos, 18-23 April 2004. Turkish Marine Research Foundation, Istanbul, 84-149.

Morgulis A, Coulouris G, Raytselis Y, Madden TL, Agarwala R, Schäffer AA (2008) Database indexing for production MegaBLAST searches. Bioinformatics 24: 1757-1764.

Padilla DK (2010) Context-dependent impacts of a non-native ecosystem engineer, the Pacific oyster Crassostrea gigas. Integrative and Comparative Biology 50: 213-225.

Poppe G, Goto Y (2000) European Seashells Vol. II (Scaphopoda, Bivalvia, Cefalopoda). ConchBooks, Hackenheim, 221 pp. 
Reise K (1998) Pacific oysters invade mussel beds in the European Wadden Sea. Senckenbergiana maritima 28: 167-175.

Reise K, Buschbaum C, Büttger H, Rick J, Wegner KM (2017) Invasion trajectory of Pacific oysters in the northern Wadden Sea. Marine Biology 164: 68-68.

Ruesink JL, Lenihan HS, Trimble AC, Heiman KW, Micheli F, Byers JE, Kay MC (2005) Introduction of non-native oysters: Ecosystem effects and restoration implications. Annual Review of Ecology, Evolution, and Systematics 36: 643-689.

Shatkin G, Shumway SE, Hawes R (1997) Considerations regarding the possible introduction of the Pacific oyster (Crassostrea gigas) to the Gulf of Maine: A review of global experience. Journal of Shellfish Research 16: 463-477.

Skolka M, Gomoiu MT (2004) Specii invazive în Marea Neagră. Impactul ecologic al pătrunderii de noi specii în ecosistemele acvatice [Invasive species in the Black Sea. Ecological impact of new species entering aquatic ecosystems]. Ovidius University Press, Constanța, 185 pp. [in Romanian]

Teacă A, Begun T, Surugiu V, Gomoiu MT (2010) Changes in the structure of the rocky mussels littoral biocoenosis from the Romanian Black Sea coast. Analele Științifice ale Universității “Al I Cuza” Iași, Biologie Animală 56: 7-22.

Troost K (2010) Causes and effects of a highly successful marine invasion: Case-study of the introduced Pacific oyster Crassostrea gigas in continental NW European estuaries. Journal of Sea Research 64: 145-165.

van Broekhoven W (2005) Microfaunal diversity on beds of the Pacific oyster (Crassostrea gigas) in the Oosterschelde estuary. MSc thesis: University of Groningen, the Netherlands, $36 \mathrm{pp}$.

Zaharia T, Crivăț M (2017) Creşterea dirijată a stridiei japoneze (Crassostrea gigas) la litoralul românesc [Directed growth of the Japanese oyster (Crassostrea gigas) in the Romanian littoral zone]. In: Zaharia T, Niță VN, Nenciu MI (Eds) Bazele acvaculturii marine în România [The bases of marine aquaculture in Romania]. CD PRESS, Bucureşti, 28-49. [in Romanian]

Zenethos A, Gofas S, Russo G, Templado J (2003) CIESM Atlas of Exotic Species in the Mediterranean. Vol. 3. Molluscs. CIESM Publishers, Monaco, 376 pp.

Zhang Z, Schwartz S, Wagner L, Miller W (2000) A Greedy Algorithm for Aligning DNA Sequences. Journal of Computational Biology 7: 203-214.

Zwerschke N, Emmerson MC, Roberts D, O’Connor NE (2016) Benthic assemblages associated with native and non-native oysters are similar. Marine Pollution Bulletin 111: 305-310. 